\title{
POLITICAL GEOGRAPHY
}


Also by Richard Muir

Modern Political Geography

Geography, Politics and Behaviour (with Ronan Paddison) 


\section{POLITICAL GEOGRAPHY}

A New Introduction

Richard Muir

University College of Ripon and York St John

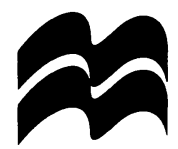




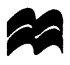

\section{(C) Richard Muir 1997}

All rights reserved. No reproduction, copy or transmission of this publication may be made without written permission.

No paragraph of this publication may be reproduced, copied or transmitted save with written permission or in accordance with the provisions of the Copyright, Designs and Patents Act 1988, or under the terms of any licence permitting limited copying issued by the Copyright Licensing Agency, 90 Tottenham Court Road, London W1P 9HE.

Any person who does any unauthorised act in relation to this publication may be liable to criminal prosecution and civil claims for damages.

The author has asserted his rights to be identified as the author of this work in accordance with the Copyright, Designs and Patents Act 1988.

First published 1997 by

MACMILLAN PRESS LTD

Houndmills, Basingstoke, Hampshire RG21 6XS

and London

Companies and representatives

throughout the world

ISBN 978-0-333-64189-7

ISBN 978-1-349-25628-0 (eBook)

DOI 10.1007/978-1-349-25628-0

A catalogue record for this book is available from the British Library

This book is printed on paper suitable for recycling and made from fully managed and sustained forest sources.

$\begin{array}{rrrrrrrrrr}10 & 9 & 8 & 7 & 6 & 5 & 4 & 3 & 2 & 1 \\ 06 & 05 & 04 & 03 & 02 & 01 & 00 & 99 & 98 & 97\end{array}$

Copy-edited and typeset by Povey/Edmondson Tavistock and Rochdale, England 
For little Kieran, without whom this book would have been finished much sooner 


\section{Contents}

List of boxes, maps and tables

Acknowledgements

Introduction

ix

$\mathrm{xi}$

1 The Politics of Territory and Place 5

Human territoriality $\quad 6$

$\begin{array}{ll}\text { Politics and place } & 17\end{array}$

2 Society and Space, Nation and State 26

$\begin{array}{ll}\text { Territoriality and social evolution } & 27\end{array}$

Nations, nationality and citizenship $\quad 38$

$\begin{array}{ll}\text { State and nation, nation and territory } & 47\end{array}$

3 The Growth of the State 66

$\begin{array}{ll}\text { The state, armed and evolving } & 67\end{array}$

$\begin{array}{ll}\text { After the absolutist state } & 78\end{array}$

The nature of the state $\quad 82$

4 The Modern State $\quad \mathbf{8 8}$

$\begin{array}{ll}\text { The modern leviathan } & 88\end{array}$

The decline of the state? $\quad 98$

5 The State from Within 114

$\begin{array}{ll}\text { Government and territory } & 115\end{array}$

$\begin{array}{ll}\text { Cores and peripheries } & 121\end{array}$

$\begin{array}{ll}\text { Migration and the state } & 125\end{array}$

City, megacity, state and world 140

$\begin{array}{ll}\text { Divide to rule } & 146\end{array}$

6 The International Dimension 154

Approaches to International Relations $\quad 155$

$\begin{array}{ll}\text { Interfaces } & 163\end{array}$

$\begin{array}{ll}\text { Political geography and war } & 173\end{array}$

$\begin{array}{ll}\text { Policy, decision and place } & 180\end{array}$

7 Geography, the State and the Third World 187

Visions of dependency and the aftermath of empire 188

Imperialism and colonial boundaries - the African problem 195

Internal colonialism and political integration $\quad 201$

Decolonisation, the 'soft' state and the collapsed state 206

8 Geopolitics, Globalisation and World Systems 213

$\begin{array}{ll}\text { The geopolitical tradition } & 214\end{array}$ 
Critical geopolitics

World-systems theory

Globalisation and world unity

9 Politics of the Environment

Sovereignty and the biosphere

Pressure groups, parties and decision-making

Conclusion: The Shape of Things to Come? 


\section{List of Boxes, Maps and Tables}

Boxes

1.1 Human nature $\quad 8$

$\begin{array}{ll}1.2 \text { Gottmann's theories of territoriality } & 16\end{array}$

$\begin{array}{ll}1.3 \text { Culture } & 18\end{array}$

1.4 David Harvey and time-space compression 22

2.1 Indigenous peoples and their plight 34

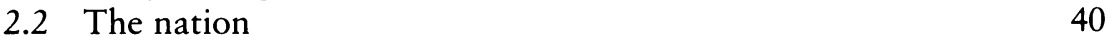

2.3 National character 45

2.4 Citizenship 49

2.5 Sovereignty 50

3.1 Stephen B. Jones and the 'unified field theory' of state creation 69

3.2 Friedrich Ratzel and the state as an organism 71

$\begin{array}{ll}\text { 3.3 Defending the territorial state } & 77\end{array}$

3.4 Parliamentary Enclosure $\quad 80$

3.5 Capital accumulation $\quad 86$

4.1 The corporate state 93

4.2 The state and welfare 95

4.3 Peter J. Taylor and the state as a container 100

$\begin{array}{lll}4.4 & \text { Supra-national regionalism } & 104\end{array}$

$\begin{array}{ll}\text { 4.5 The transnational corporation } & 109\end{array}$

5.1 Hartshorne and the 'state idea' 116

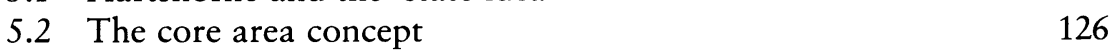

$\begin{array}{ll}5.3 \text { Social justice } & 144\end{array}$

$\begin{array}{lll}5.4 & \text { Electoral geography } & 149\end{array}$

$\begin{array}{lll}6.1 & \text { Power systems } & 161\end{array}$

$\begin{array}{lll}6.2 & \text { Frontiers } & 167\end{array}$

6.3 Environmental determinism 185

$\begin{array}{lll}7.1 & \text { Interpretations of empire } & 192\end{array}$

$\begin{array}{ll}8.1 \text { Mackinder and the heartland } & 217\end{array}$

$\begin{array}{lll}8.2 & \text { Kondratieff cycles } & 234\end{array}$

8.3 The Pacific rim and Asian values 239

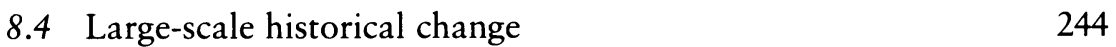

9.1 Hardin and the tragedy of the commons 260

$\begin{array}{ll}9.2 \text { Pluralism } & 272\end{array}$ 


\section{- Maps}

1 Territories of the !Ko bushmen 32

2 Yugoslavia: ethnic divisions and territories, $1995 \quad 62$

3 Minority nationalism in Western Europe 103

4 Growth of membership of the EEC/EC/EU 106

5 States that have failed to overcome cultural divisions:

Cyprus, Czechoslovakia and Yugoslavia 117

6 Variations in per capita GDP between regions in the UK 124

7 The flight of refugees from Rwanda, $1994 \quad 130$

8 Russian minorities living outside Russia 138

9 Political and economic orientations within Europe 170

10 The division of Africa into colonial territories, 1914

11 Somalia, an example of a collapsed African state 204

12 Three versions of the geopolitical world 219

13 Hotspots in recent campaigns against roadbuilding in the UK

14 Pressure points in South-East Asia 285

\section{$\square$ Tables}

5.1 Referenda in the Baltic Republics 


\section{Acknowledgements}

The author and publishers acknowledge with thanks permission from the following to reproduce copyright material:

Lynne Rienner Publishers, for the quotation from R. B. J. Walker, One World, Many Worlds (1988) in Chapter 6.

The Guardian, for the quotation from Clare Travena, (C) The Guardian (1995) in Chapter 5.

Macmillan, for the quotation from Thomas Hardy, 'Departure' (1899), in The Complete Poems, in the Introduction.

Chatto \& Windus, for the quotation from Aldous Huxley, Themes and Variations (1950) in Chapter 2.

Alternatives, for the quotation from R. B.J. Walker, 'Security, Sovereignty and the Challenge of World Politics' (1990) in Chapter 3.

Archives Européennes de Sociologie, for the quotation from M. Mann, 'The Autonomous Power of the State: Its Origins, Mechanisms and Results' (1984) in Chapter 4.

Clarendon Press, for the quotation from A. J.P. Taylor, The Struggle for Mastery in Europe, 1848-1918 (1954) in Chapter 7.

Review of African Political Economy, for the quotation from B. Davidson, 'The Crisis of the Nation-States of Africa' (1990) in Chapter 7.

Newsweek, for the quotation from Frank Borman (1968) in Chapter 8.

Every effort has been made to contact all the copyright-holders, but if any have been inadvertently omitted the publishers will be pleased to make the necessary arrangement at the earliest opportunity. 